\title{
Genetic and Phenotypic Characterization of Grapevine vein clearing virus from Wild Vitis rupestris
}

\author{
Steven Beach, Michael Kovens, LeAnn Hubbert, Shae Honesty, Qiang Guo, Daniel Pap, Ru Dai, \\ Laszlo Kovacs, and Wenping Qiu
}

First, second, third, fourth, fifth, sixth, seventh, and ninth authors: Center for Grapevine Biotechnology, Darr School of Agriculture, Missouri State University, Mountain Grove, MO 65711; and eighth author: Department of Biology, Missouri State University, Springfield, MO 65897. Current address for Q. Guo: Department of Plant Biology, Michigan State University, East Lansing 48824.

Current address for D. Pap: Department of Viticulture \& Enology, University of California, Davis 95616.

Accepted for publication 21 August 2016.

\begin{abstract}
Grapevine vein clearing virus (GVCV), a new member of the genus Badnavirus in the family Caulimoviridae, is associated with a vein clearing and vine decline disease that severely affects grape production and berry quality in commercial vineyards in the Midwest region of the United States. In this paper, the genetic and phenotypic characteristics of GVCV-VRU1 and GVCV-VRU2, two isolates from wild Vitis rupestris grapevines in their native habitat, are described. The GVCV-VRU1 genome is 7,755 bp long while the GVCV-VRU2 genome consists of 7,725 bp, both of which are different from the genome of the GVCV-CHA isolate $(7,753 \mathrm{bp})$, which was originally discovered in the grape cultivar 'Chardonel'. The nucleotide sequence identity among GVCV-VRU1, GVCV-VRU2, and GVCV-CHA ranges from 91.6 to $93.4 \%$, and open reading frame (ORF) II is the most

divergent ORF with only 83.3 to $88.5 \%$ identity. Sequence analysis of the ORF II indicated that GVCV isolates genetically similar to GVCV-VRU1 and GVCV-VRU2 also are present in commercial vineyards. Symptoms of GVCV-VRU1- or GVCV-VRU2-infected wild V. rupestris grapevine appeared initially as translucent vein clearing on young leaves and progressed to vein necrosis on mature leaves. Inoculation of GVCV-VRU1 or GVCVVRU2 by grafting onto grape cultivar Chardonel resulted in mild mottle and leaf distortion. The natural range of wild $V$. rupestris grapevines overlaps with commercial vineyards in the Midwestern United States. Therefore, the discovery of GVCV isolates in wild $V$. rupestris grapevines has important implications for epidemics and management of the GVCVassociated disease.
\end{abstract}

Grapevine vein clearing virus (GVCV) is a new species in the genus Badnavirus of the family Caulimoviridae (Zhang et al. 2011). GVCV-associated disease poses a serious threat to grape production in the Midwest region of the United States (Guo et al. 2014). Symptoms were observed first on Vitis vinifera 'Chardonnay' grapevines in the state of Missouri (Qiu et al. 2007; Zhang et al. 2011). Later, GVCV was also detected in other major $V$. vinifera cultivars including Cabernet Sauvignon, Cabernet franc, Riesling, and interspecific hybrids Chardonel, Vignoles, Vidal Blanc, and Valvin Muscat in the states of Missouri, Arkansas, Illinois, and Indiana. The leaves of diseased vines are small, deformed and rolling downward with translucent veins and mosaic patterns. The diseased vines have short internodes, brownish abnormal berries, and eventually loss productivity as a result of severe vine decline. Since the first report of the disease on the grape cultivar Chardonnay in 2004, multiple surveys of vineyards within the Midwest United States have shown increased incidence of the disease, indicating that the virus continues to spread among grape cultivars. Insect vectors of the virus are elusive and currently under investigation.

The genome of GVCV is a circular, double-stranded DNA of $7,753 \mathrm{bp}$. The plus-strand of the genome encodes three open reading frames (ORFs). ORF I- and ORF II-encoded proteins of badnaviruses have been found to be associated with virions (Jacquot et al. 1996). The ORF III-encoded polyprotein is predicted to be processed into

Corresponding author: W. Qiu; E-mail address: WenpingQiu@missouristate.edu

*The $\boldsymbol{e}$-Xtra logo stands for "electronic extra" and indicates that four supplementary tables are published online.

(C) 2017 The American Phytopathological Society coat protein, movement protein, and reverse transcription (RT)/ $\mathrm{RNaseH}$ by self-encoded proteinase activity (Hull et al. 2005). To start replication of a viral genome in the family Caulimoviridae, RNA polymerase II first makes an intermediate RNA molecule, which has short, redundant terminal sequences. A nascent genomic DNA strand is then synthesized from the intermediate RNA molecule by RT using tRNAMET as a primer (Schoelz 2008). The divergence of RT and $\mathrm{RNaseH}$ nucleotide sequences is used as a criterion for species classification and for the reconstruction of virus phylogenetic relationships (Hull et al. 2005). Sequencing of the partial genome suggested that GVCV exists as genetically diverse populations in vineyards. Sequence identity of GVCV isolates from different grape cultivars in vineyards across the Midwest ranges from 96 to $98 \%$ at the nucleotide level in two sequenced regions (Guo et al. 2014). However, GVCV populations do not cluster according to grape variety or geographical location (Guo et al. 2014).

$V$. rupestris played a significant role in the effective control of the catastrophic phylloxera epidemic in Europe in the late 19th century (Husmann 1880). Many varieties of current rootstocks (for example, V. rupestris 'St. George') have been bred by using V. rupestris as a parent because of its resistance to phylloxera, tolerance to drought, deep and robust root system, and excellent rooting and callusing ability. By virtue of its strong resistance to fungal and oomycete pathogens of grapes, $V$. rupestris has also become a valuable genetic resource for breeding hybrid grape varieties since the pioneering work of Missouri and French grape breeders in the 19th century. For instance, four out of five founder selections in the current downy mildew-resistant grape cultivars contain $V$. rupestris genome in their genetic background (Di Gaspero et al. 2012). V. rupestris is native to the Midwestern and Eastern regions of the United States. Its native range covers the area of 10 states from Pennsylvania to 
Texas. It grows as a shrub on gravel bars along rivers and dry beds of intermittent creeks. While $V$. rupestris is extant in the wild, its populations have been severely depleted throughout most of its habitats, with the exception of the Ozarks region in Missouri and Arkansas where it forms sporadic populations (Pavek et al. 2003).

Native wild grapevines host viruses. Grapevine leafrollassociated virus-2 (GLRaV-2) and GLRaV-3, Grapevine virus A, and Grapevine virus $B$ were found in free-living $V$. californica and its hybrids in California (Klaassen et al. 2011). Grapevine red blotch-associated virus ( $\mathrm{GRBaV})$ was detected in V. californica and hybrids in the riparian zones that are distant to and immediately adjacent to commercial vineyards (Bahder et al. 2016; Perry et al. 2016). Viruses that previously were not reported in cultivated grapevines were also discovered in native wild $V$. aestivalis in the eastern United States (Ghanem-Sabanadzovic and Sabanadzovic 2010). These findings indicate the existence of natural reservoirs of viruses in wild grapevines. In recent years, the high throughput sequencing of virus-derived fragments has enabled researchers to find many known and unknown viruses in wild herbaceous plants (Roossinck 2012; Roossinck et al. 2010, 2015). New viruses can spread from reservoirs of wild plants in their native habitats to cultivated crops by insect transmission or arise as preexisting genetic variants which then jump from their original hosts to new species (Elena et al. 2014). In the same way, viruses in domestic crops can spread to wild plants (Jones 2009; Roossinck and García-Arenal 2015). In an investigation of 21 wild Cucurbita pepo populations for the presence of five viruses in the genus Potyvirus, virus infection frequency varied from 0 to $74 \%$ (Prendeville et al. 2012). Blueberry leaf mottle virus (BLMV) was discovered in native bushes of wild blueberry (Vaccinium corymbosum, V. myrtilloides, and $V$. angustifolium), and thought to be transmitted from native wild plants to cultivated blueberries (Sandoval et al. 1995). On the other hand, the presence of new and emerging viruses in cultivated blueberry and cranberry plants in the United States raised concern about the spread of these viruses from cultivated to their wild relatives (Martin et al. 2012). This speculation is supported by the fact that BLMV was detected in pollen and can be transmitted by insects. Over centuries, agricultural practices and expansion of agricultural areas have enhanced epidemics of existing and new viruses in crops worldwide (Jones 2009).

Until this point GVCV has been solely detected in cultivated grapevines in commercial vineyards in the Midwest United States (Guo et al. 2014; Zhang et al. 2011). The primary objective of the present study was to investigate if GVCV exists in wild $V$. rupestris grapevines that are native to the Midwest and characterize their genetic and phenotypic relationships with isolates from commercial vineyards. After GVCV isolates were found in wild grapevines, we sequenced the whole genome of the two new isolates and analyzed their genome sequences in comparison with the GVCV-CHA reference genome that was first described in a cultivated grapevine Chardonel, and conducted genetic variability analysis of the ORF II regions in selected GVCV isolates. We also investigated symptoms of wild GVCV isolates on Chardonel cultivar after graft-inoculation. The results from this study provided new insights into potential reservoir and spreading routes of GVCV and compelled us to reconsider the management strategies of the GVCV-associated disease.

\section{MATERIALS AND METHODS}

Collection and propagation of wild $V$. rupestris and cultivated grapevines. A total of $35 \mathrm{~V}$. rupestris samples were collected from four locations in the states of Oklahoma and Missouri in 2012, 2013, and 2014 for a survey of the virus. They are listed in Supplementary Table S1. A total of 20 grapevines from four commercial vineyards in Missouri and 22 grapevines from a vineyard in Arkansas were sampled for the genetic diversity study (Supplementary Table S2). Fully developed leaves and stems were collected from each plant, placed with a moist paper towel into a plastic bag, and stored in a cooler with ice until they were transported to the laboratory. Shoots of vine samples 'VRU89' and 'VRU1401' to 'VRU1406' were sampled, propagated by rooting three-node green cuttings, and grown in a greenhouse at the Missouri State Fruit Experiment Station in Mountain Grove, Missouri.

Graft transmission of GVCV isolates from wild V. rupestris to Chardonel vines. Green softwood cuttings with two nodes (scion) of virus-free Chardonel grapevines were grafted onto green softwood cuttings of virus-infected 'VRU89' and 'VRU1405' grapevines with one node (rootstock) by the wedgegrafting technique. In reciprocal grafting, virus-infected 'VRU89' and 'VRU1405' grapevines were grafted as the scion onto virus-free Chardonel grapevines as rootstocks. Three replicates of each rootstock/scion combination were performed. The ends of rootstocks were dipped in Rhizopon AA no. 1 rooting hormone powder (The Hortus USA Corp., Earth City, MO) and placed in sponge plugs in a Styrofoam tray under mist until four or more roots emerged from the rootstock. Rooted vines were then transferred to potted soil. A single node of both the scion and the rootstock was allowed to grow into a full vine. Symptoms on grafted vines were visually inspected weekly.

Extraction of DNA. Leaf tissues $(100 \mathrm{mg})$ were flash frozen in liquid nitrogen and ground into a fine powder using a mortar and pestle. Total DNA was extracted with a DNeasy Mini Plant Kit (Qiagen Inc., Valencia, CA), and DNA was eluted in $50 \mu \mathrm{lof} \mathrm{dH}_{2} \mathrm{O}$. DNA concentration was measured using a NanoDrop 2000 spectrophotometer (NanoDrop Products, Wilmington, DE).

Primers for amplifying GVCV-specific fragments and polymerase chain reaction. A set of primers was designed from the GVCV reference genome sequence (GenBank accession number JF301669) and used to detect the presence of GVCV by PCR. Additional sets of primers were designed for amplifying three overlapping fragments covering the entire genome of GVCV (Supplementary Table S3).

The PCRs were performed with Platinum High Fidelity Taq DNA polymerase according to the protocol provided by Life Technologies (Grand Island, NY). The PCR reagents were composed of $1 \times$ High Fidelity Platinum Taq buffer, $2 \mathrm{mM} \mathrm{MgCl} 2,0.2 \mathrm{mM}$ dNTP, $0.2 \mu \mathrm{M}$ primers, $25 \mathrm{ng}$ of template DNA, and 1 unit of Platinum Taq. The PCR thermocycler program was as follows: initial denaturation for $1 \mathrm{~min}$ at $94^{\circ} \mathrm{C} ; 35$ cycles of denaturation at $94^{\circ} \mathrm{C}$ for $30 \mathrm{~s}$, annealing at a temperature specific for each set of primers for $40 \mathrm{~s}$, and extension at $72^{\circ} \mathrm{C}$ for $1 \mathrm{~min}$ for fragments of less than $1 \mathrm{~kb}$ or $1 \mathrm{~min} / \mathrm{kb}$ for fragments of more than $1 \mathrm{~kb}$; final extension at $72^{\circ} \mathrm{C}$ for $10 \mathrm{~min}$.

The DNA fragments were separated on a $1 \%$ agarose gel in $0.5 \times$ Tris-borate EDTA buffer ( $45 \mathrm{mM}$ Tris-borate, $1 \mathrm{mM}$ EDTA) by electrophoresis and visualized and recorded under UV illumination after staining with GelRed (Biotium Inc., Hayward, CA).

Cloning and sequencing of GVCV-VRU1 and GVCVVRU2 genomes. Three overlapping DNA fragments were amplified from the genomic DNA of GVCV-positive wild $V$. rupestris VRU89 and VRU1405 samples by PCR and purified from agarose gel. They were then ligated into the $\mathrm{pCR} 8 / \mathrm{GW} / \mathrm{TOPO}$ vector plasmid using the Gateway TOPO TA Cloning Kit (Invitrogen, Carlsbad, CA).

Recombinant pCR8/GW/TOPO constructs were transformed into chemically competent One Shot TOP10 E. coli cells by heatshock. The bacteria transformed with recombinant plasmids were cultured on sterilized Luria-Bertani (LB) agar medium plates with spectinomycin at a concentration of $100 \mu \mathrm{g} / \mathrm{ml}$ in a $37^{\circ} \mathrm{C}$ incubator. Individual colonies were selected and cultured in liquid LB medium with spectinomycin in a $37^{\circ} \mathrm{C}$ shaker overnight at $220 \mathrm{rpm}$. Recombinant plasmid DNA was isolated using the QIAprep 
Spin Miniprep Kit (QIAGEN) and confirmed to contain the GVCV fragment by PCR with GVCV-specific primers as well as universal GW1 primer (5'-GTTGCAACAAATTGATGAGCAATGC-3') and GW2 primer (5'-GTTGCAACAAATTGATGAGCAATTA-3'). The nucleotide sequence of the entire insert was acquired by the primerwalking strategy. The sequences were assembled and analyzed using the Vector NTI program (Invitrogen).

\section{RESULTS}

Discovery of GVCV in wild $V$. rupestris accessions. To investigate if GVCV was present in wild $V$. rupestris grapevines, 35 samples from three locations in Missouri (Wolf Creek, 4 samples; Little Piney River, 3 samples; and Swan Creek, 21 samples) and one location in Oklahoma (Buzzard Creek: 7 samples) were tested by PCR using three sets of GVCV-specific primers for amplifying DNA fragments of 246, 461, and 2,580 bp, respectively. GVCVspecific fragments of 461 and $2,580 \mathrm{bp}$ were detected first in eight samples. To verify these results and acquire the genome sequences, we designed additional sets of GVCV-specific primers to amplify three genomic fragments that cover the entire GVCV genome and share overlapping sequences between each fragment. We were able to obtain the three overlapping DNA fragments only from the two samples, VRU89 and VRU1405. These two wild grapevines showed distinct vein clearing and necrosis symptoms in their native habitats. GVCV isolates from wild $V$. rupestris are thus designated as GVCVVRU1 and GVCV-VRU2. The genomes of these two GVCV isolates were then sequenced, assembled, and analyzed. Their association with disease on cultivated grapevines was further investigated.

Genome analysis of GVCV isolates from wild $V$. rupestris. The genome of GVCV-VRU1 and GVCV-VRU2 is 7,755 and 7,725 bp long, respectively. In comparison, the GVCV-CHA genome is 7,753 bp long (Table 1). A majority of the genome length difference in GVCVVRU2 is due to the short intergenic region (IGR) of $883 \mathrm{nt}$, which is 30 nt shorter than GVCV-VRU1, and 34 nt shorter than GVCV-CHA (Table 1). Sequence comparisons between the three isolates showed that GVCV-VRU1 and GVCV-VRU2 are the most closely related with identities of $93.4 \%$ even though they are largely different in length.

The first 12 nucleotides (5'-TGGTATCAGAGC) of both the GVCV-VRU1 and the GVCV-VRU2 genomes were complementary to the $3^{\prime}$-end 12 nucleotides of the plant tRNAMET consensus sequences ( $3^{\prime}$-ACCAUAGUCUCG-5'), predicting that they can serve as an annealing site for tRNA ${ }^{\mathrm{MET}}$ for priming the synthesis of genomic molecules, as suggested previously for other members of the family Caulimoviridae (Schoelz 2008). The IGR of GVCV-VRU1 and GVCVVRU2 shared 90.7 and $90.2 \%$ identical nucleotides with the IGR of GVCV-CHA with distinct insertions and deletions among them (Table 1).

The ORF II region was the most divergent among the three coding regions. The ORF II of GVCV-CHA and GVCV-VRU2 was $381 \mathrm{nt}$ in length, while the ORF II of GVCV-VRU1 had 390 nt. The difference in length was due to a $9 \mathrm{nt}$ indel starting at nucleotide 1,373 in the GVCV-VRU1 genome. GVCV-VRU2 and GVCV-CHA do not contain the signature $9 \mathrm{nt}$ insert in the ORF II of GVCV-VRU1. Sequencing of DNA fragments covering the entire ORF II in additional recombinant plasmids further confirmed the presence of the $9 \mathrm{nt}$ indel in the ORF II of GVCV-VRU1. The overall identity of ORF II of the three isolates was 83.4 to $88.5 \%$ at the nucleotide sequence level (Table 2).

Genetic variability of GVCV isolates in commercial vineyards. A survey of seven grape cultivars indicated a high incidence of GVCV-CHA isolates in five commercial vineyards. Based on the results that the ORF II region is the most variable among the three GVCV isolates (Table 2), we then cloned and sequenced the entire ORF II region of four selected GVCV isolates from commercial vineyards for further analysis of GVCV genetic diversity (Fig. 1; Supplementary Table S4). Sequence analysis of ORF II of four selected GVCV isolates revealed a 83.5 to $99.2 \%$ nucleotide identity in comparison with the sequence of reference isolate GVCV-CHA. Multiple single nucleotide polymorphisms (SNPs) were found throughout the ORF II regions.

The ORF II nucleotide sequences of the GVCV-CMV2 are $99.2 \%$ identical to GVCV-VRU2 and do not have the $9 \mathrm{nt}$ insertion. The ORF II nucleotide sequence of GVCV-CVV5 shares $98.4 \%$ identity with those of GVCV-CHA, and thus were considered as a GVCVCHAlike isolate. The ORF II regions of the GVCV-ARK244 and GVCVCMV3 have the $9 \mathrm{nt}$ insertion as in GVCV-VRU1. Interestingly, the remaining sequences of GVCV-CMV3 ORF II are more similar to GVCV-VRU1 than to GVCV-VRU2. The phylogenetic analysis of the seven GVCV isolates indicated that GVCV-CMV2 is closely related to GVCV-VRU2, GVCV-CVV5 to GVCV-CHA, GVCVARK244 to GVCV-VRU1, respectively (Fig. 1). These results indicated that the GVCV isolates similar to wild GVCV-VRU1 and GVCV-VRU2 are present in cultivated grapevines in Missouri and Arkansas.

Association of GVCV-VRU1 and GVCV-VRU2 with clearing and necrosis on $\boldsymbol{V}$. rupestris. Distinct symptoms were observed on GVCV-VRU1 and GVCV-VRU2 infected wild V. rupestris 'VRU89' and 'VRU1405' grapevines in native habitats (Fig. 2). Translucent vein clearing was observed on young leaves of both GVCV-VRU1 and GVCV-VRU2-infected grapevines (Fig. 2B and E). On the basal mature leaves, vein clearing developed into necrotic spots (Fig. 2C). Necrotic spots were observed around translucent veins on 'VRU1405' vine (Fig. 2E). None of these symptoms were observed on wild $V$. rupestris grapevines that tested negative for GVCV.

Symptoms on wild grapevines in native habitats can be caused by various abiotic and biotic factors. To investigate if the GVCV-infected wild grapevine develops symptoms under controlled conditions, we collected cuttings of VRU89 and VRU1405 grapevines from their

TABLE 1. Comparison of the whole genome, intergenic region (IGR) and three open reading frames (ORFs) of three Grapevine vein clearing virus (GVCV) isolates

\begin{tabular}{|c|c|c|c|c|c|}
\hline Isolates & Genome length & IGR & ORF I Start-stop (length ${ }^{\mathrm{a}}$ ) & ORF II Start-stop (length) & ORF III Start-stop (length) \\
\hline GVCV-CHA & 7,753 bp & 7,321-7,753: 1-484 (917 nt) & $485-1,111(624 \mathrm{nt})$ & $1,112-1,495(381 \mathrm{nt})$ & $1,495-7,320(5,823 \mathrm{nt})$ \\
\hline GVCV-VRU1 & $7,755 \mathrm{bp}$ & 7,326-7,755: 1-483 (913 nt) & $484-1,110(624 \mathrm{nt})$ & $1,111-1,503(390 \mathrm{nt})$ & $1,503-7,328(5,826 \mathrm{nt})$ \\
\hline GVCV-VRU2 & $7,725 \mathrm{bp}$ & 7,317-7,725: 1-474 (883 nt) & $475-1,104(627 \mathrm{nt})$ & $1,105-1,487(381 \mathrm{nt})$ & $1,487-7,315(5,829 \mathrm{nt})$ \\
\hline
\end{tabular}

a Nucleotides do not include stop codons.

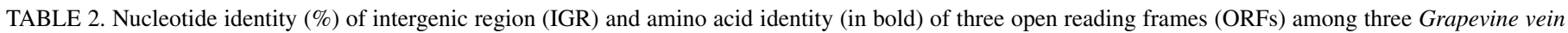
clearing virus isolates

\begin{tabular}{|c|c|c|c|c|c|c|c|c|c|c|c|c|}
\hline \multirow[b]{2}{*}{ Isolate } & \multicolumn{3}{|c|}{ IGR } & \multicolumn{3}{|c|}{ ORF I } & \multicolumn{3}{|c|}{ ORF II } & \multicolumn{3}{|c|}{ ORF III } \\
\hline & CHA & VRU1 & VRU2 & CHA & VRU1 & VRU2 & CHA & VRU1 & VRU2 & CHA & VRU1 & VRU2 \\
\hline CHA & 100.0 & & & 100.0 & 97.7 & 95.3 & 100.0 & 86.2 & 93.7 & 100.0 & 96.5 & 96.7 \\
\hline VRU1 & 90.7 & 100.0 & & 94.3 & 100.0 & 95.4 & 83.4 & 100.0 & 90.8 & 91.9 & 100.0 & 96.6 \\
\hline VRU2 & 90.2 & 91.1 & 100.0 & 92.4 & 94.3 & 100.0 & 88.5 & 88.3 & 100.0 & 92.0 & 93.8 & 100.0 \\
\hline
\end{tabular}


original native sites and propagated them in potted soil in a greenhouse. Vein clearing symptoms were again observed on young leaves of propagated VRU89 and VRU1405 vines (Fig. 3). Veinclearing symptoms appeared solely on the young leaves (Fig. 3D and F). On the mature leaves, necrotic spots appeared along major veins or terminals of minor veins (Fig. 3B and C). There was a progression of the symptoms from vein clearing to vein necrosis as leaves developed (Fig. 3D to G). For instance, the second leaf from the shoot tip showed vein clearing and few necrotic spots on the GVCV-VRU1 infected vine (Fig. 3D). Five days later, necrotic lesions were observed along the previously translucent veins (Fig. 3E).

Similarly, translucent vein clearing appeared along the major veins on the second leaf of the GVCV-VRU2-infected vine (Fig. $3 \mathrm{~F}$ ), and progressed to necrotic spots within 14 days (Fig. 3G). Necrosis and necrotic spots around veins are distinct symptoms that are associated with GVCV-VRU1 and GVCV-VRU2, in comparison with typical vein clearing on young leaves and mosaic symptoms on GVCV-CHA-infected Chardonel (Zhang et al. 2011) and $V$. rupestris 'St. George' vines. The only discernable difference between GVCV-VRU1 and GVCV-VRU2 is that the vein necrotic lesions are more pronounced and have chlorotic halos with the infection of GVCV-VRU2 on V. rupestris (Fig. 3G).

GVCV-VRU1- and GVCV-VRU2-grafted Chardonel exhibit similar symptoms as GVCV-CHA. Previous studies showed that grape cultivar Chardonel is highly susceptible to GVCV (Guo et al. 2014; Zhang et al. 2011). To compare symptoms associated with the three GVCV isolates, we grafted GVCV-VRU1-, GVCV-VRU2-, or GVCV-CHA-infected green softwood cuttings onto Chardonel grapevines. The presence of GVCV in the grafted Chardonel grapevines was confirmed by PCR using isolate-specific primers, demonstrating that GVCV-VRU1 and GVCV-VRU2 are grafttransmissible by existing as replicating episomal forms. One year after Chardonel vines were graft-inoculated with three GVCV isolates, some mature leaves showed pronounced vein clearing and distortion on GVCV-CHA-infected Chardonel vine (Fig. 4A). In contrast, only mild mottle symptoms appeared on mature leaves of GVCV-VRU1-infected Chardonel (Fig. 4B), and translucent veinclearing showed on some mature leaves of GVCV-VRU2-infected 'Chardonel' vines (Fig. 4C). However, none of GVCV-VRU1- or

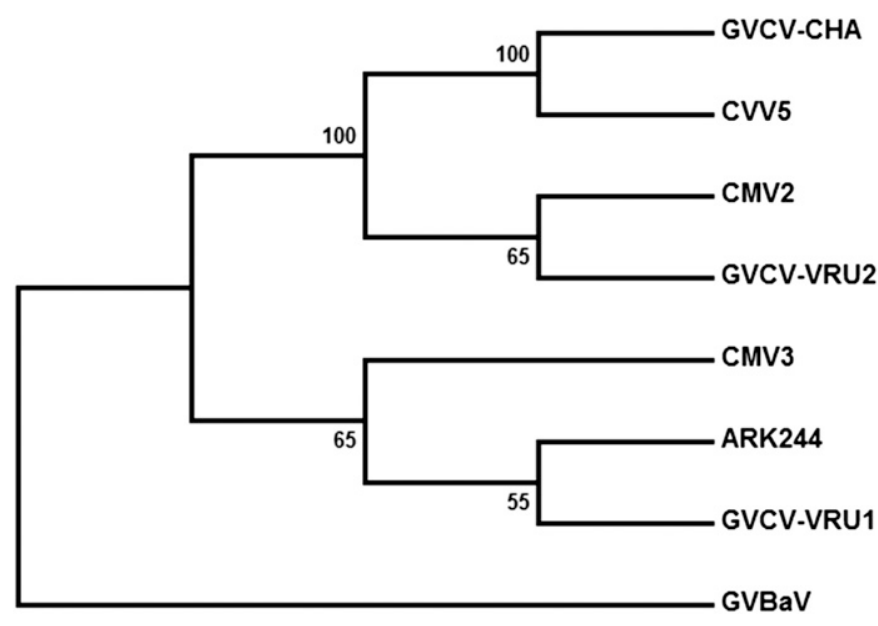

Fig. 1. Phylogenetic relationship of the two Grapevine vein clearing virus (GVCV) isolates from wild habitats and five from commercial vineyards based on the open reading frame (ORF) II regions of GVCV genome. GVCV isolate from commercial vineyards was named after acronym of vineyards for respecting the winery's identity. Branches reproduced in less than $50 \%$ of bootstrap replicates were collapsed. The rooted phylogenetic tree was constructed by the maximum likelihood method using the best models with bootstrap replicates at 1,000 in the MEGA7 software. The ORF II region of Gooseberry vein bandingassociated virus (GVBaV, GenBank accession number NC_018105) was used as an outgroup for constructing the rooted tree.
GVCV-VRU2-infected 'Chardonel' vines developed vein necrosis, as observed on $V$. rupestris vines (Figs. 2 and 3 ).

\section{DISCUSSION}

GVCV isolates VRU1 and VRU2 were identified in wild V. rupestris grapevines that exhibited vein clearing and necrosis symptoms in the Missouri Ozarks region (Figs. 2 and 3). The genomes of GVCV-VRU1 and GVCV-VRU2 are 7,755 and 7,725 bp in length, respectively. The difference in genome size among the three GVCV isolates is mainly attributed to insertions and deletions in the intergenic region (Table 1). Nucleotides of ORF II among GVCV-CHA, GVCV-VRU1, and GVCV-VRU2 isolates are the most variable, sharing 83.4 to $88.5 \%$ identity (Table 2). Similarly, the ORF II region of Gooseberry vein banding-associated virus $(\mathrm{GVBaV})$ is the most divergent among the four isolates of this virus identified so far (Xu et al. 2011). In contrast, it is the ORF VI that is evolving most rapidly among the ORF regions of Cauliflower mosaic virus (CaMV) isolates (Yasaka et al. 2014). The disparity of genetic variations among the coding regions of plant pararetroviruses suggests that these regions of viral DNA genomes in the family Caulimoviridae evolve at different rates. Since ORF II has been shown to be the most polymorphic of the three ORFs, we propose that the identity of the ORF II region can be used as criterion to differentiate GVCV isolates. If the nucleotide identity of ORF II in an isolate is less than $90 \%$ in comparison with the ORF II in the GVCV-CHA reference genome, it should be considered as a new GVCV isolate.

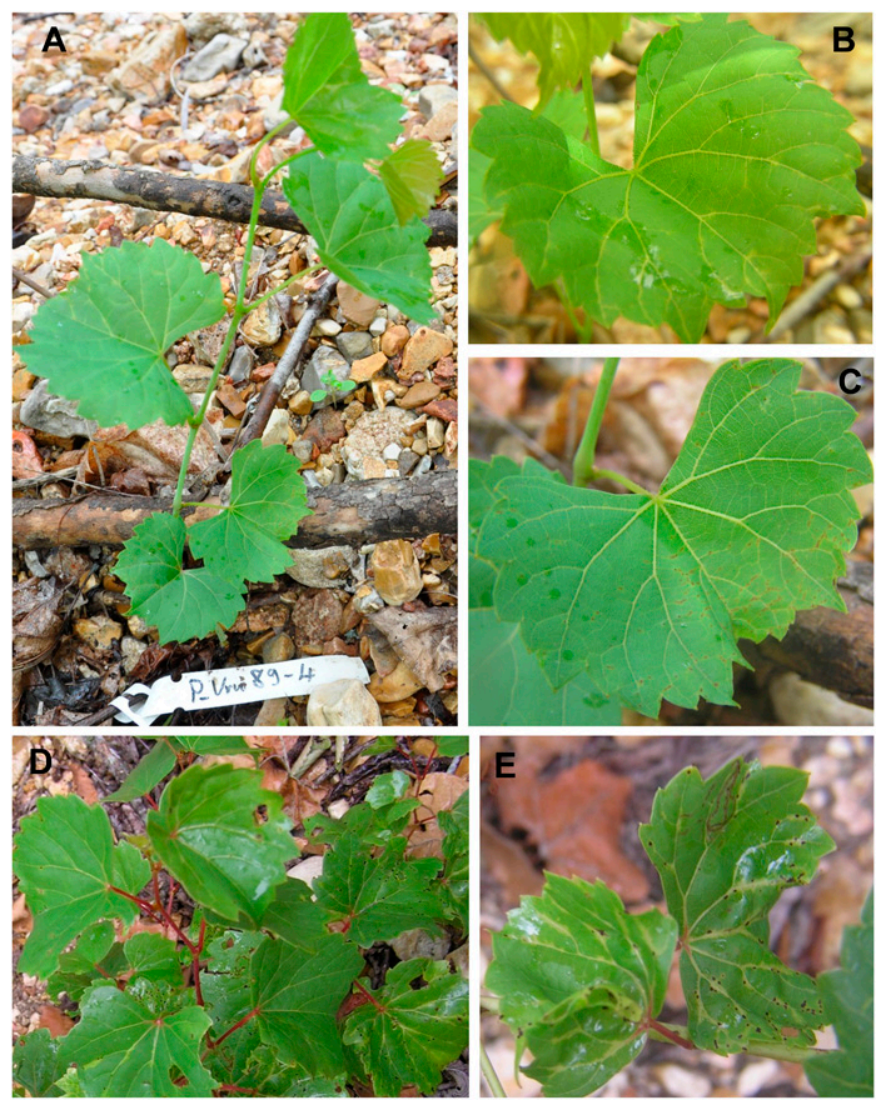

Fig. 2. Symptoms on Grapevine vein clearing virus (GVCV)-VRU1 and GVCV-VRU2 infected Vitis rupestris 'VRU89' and 'VRU1405' grapevine in native habitats. A, Symptomatic VRU89 vine showing vein clearing and necrosis; B, The third leaf from the shoot tip showing translucent vein clearing; C, A basal leaf exhibiting necrotic spots along the major veins; D, Symptomatic 'VRU 1405' vine; E, Translucent vein clearing and necrotic spots were observed on leaves of 'VRU1405' vine. 
Nucleotide sequences of viruses in the genus Badnavirus, family Caulimoviridae have a high degree of genetic heterogeneity (Borah et al. 2013). The nucleotide sequences among Banana streak virus (BSV) isolates vary from 21.8 to $33.6 \%$ differences in the
RT/RNaseH coding regions (Geering et al. 2000). Sequence analysis of RT and Zinc Finger domain demonstrated that GVCV is present as genetically diverse populations in commercial vineyards. Genotypes of grapevines also exert an influence on the sequenced regions
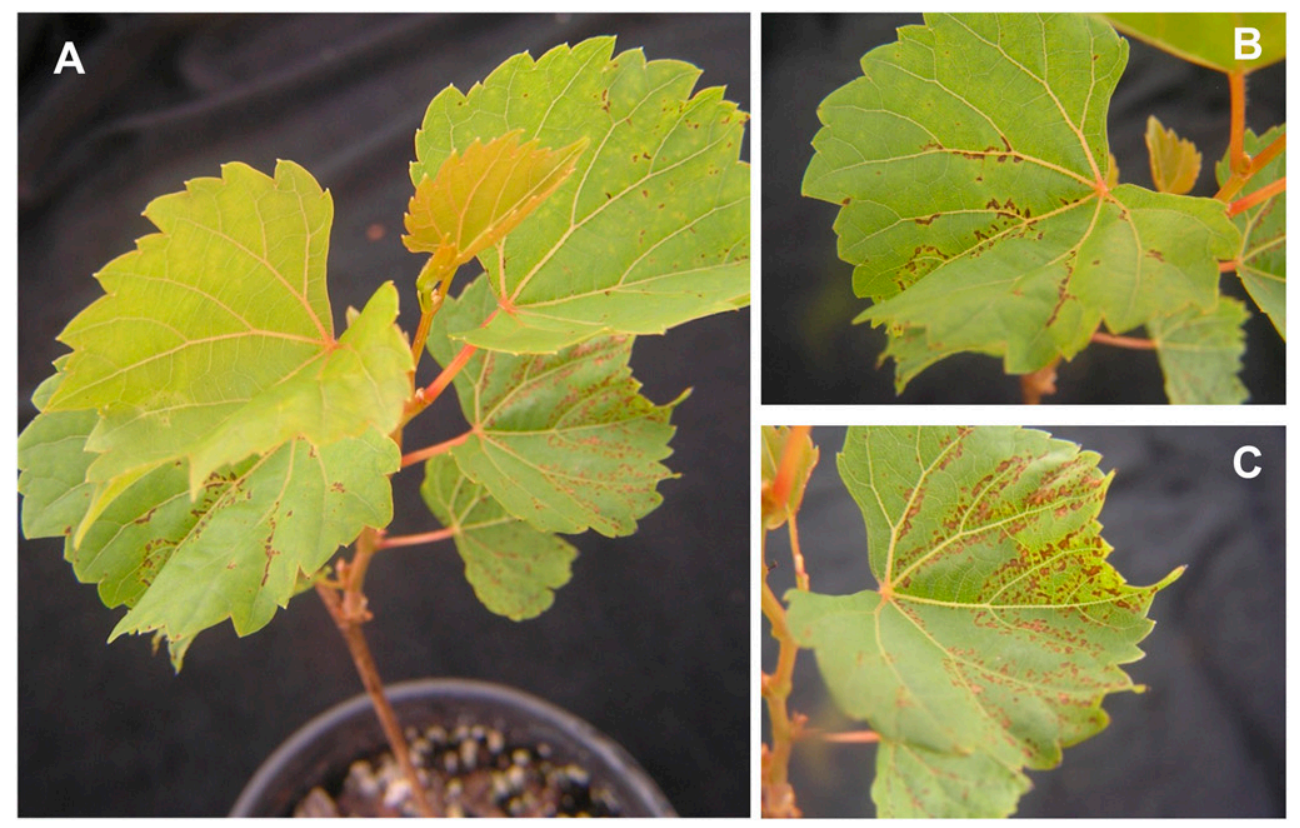

D

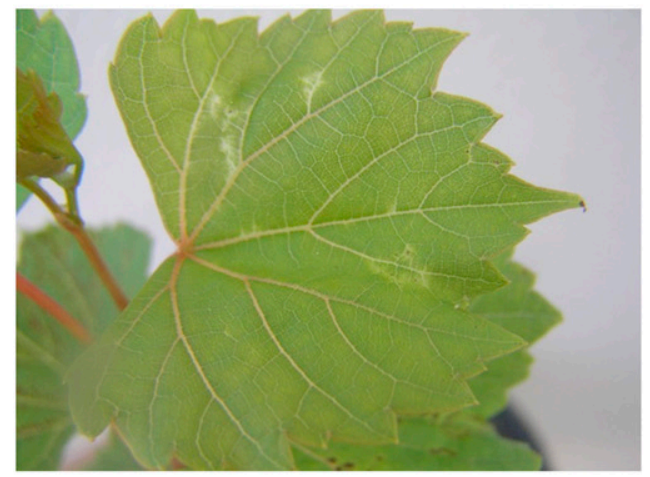

$\mathbf{F}$

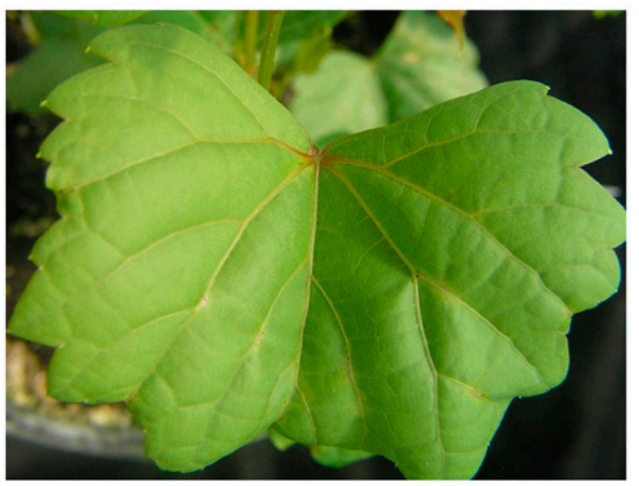

$\mathbf{E}$

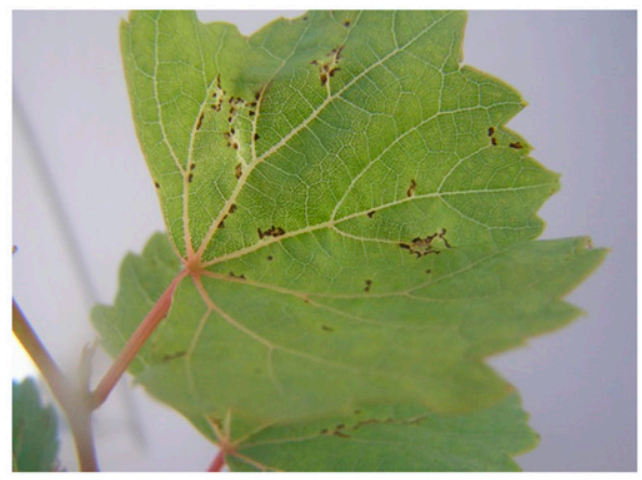

G

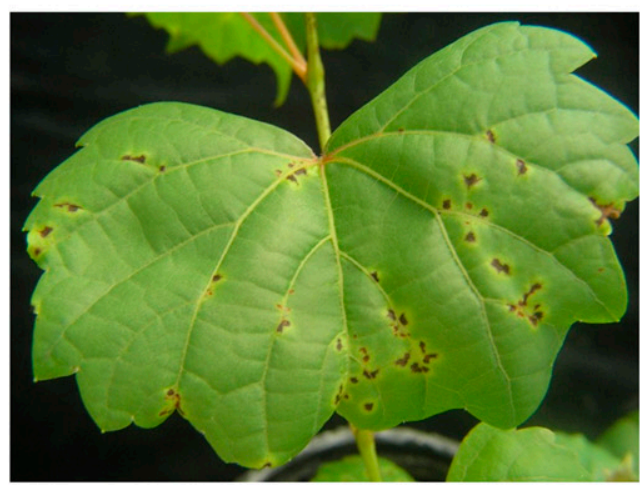

Fig. 3. Development of symptoms on Grapevine vein clearing virus (GVCV)-VRU1 infected Vitis rupestris 'VRU89' and GVCV-VRU2 infected V. rupestris 'VRU1405' grapevine in potted soil under greenhouse conditions. A, Symptoms developed 48 days after rooted hardwood cuttings of GVCV-VRU1-infected vine were planted in potted soil and grew into vines. B, The fourth leaf from the shoot tip showing necrotic spots along major veins. $\mathbf{C}$, The fifth leaf from the shoot tip showing massive necrotic spots along major vein. D, The second leaf from the shoot tip showing vein clearing when photo was taken on 10 April 2014 . E, The same leaf showing necrotic spots along veins when photo was taken on 15 April 2014, indicating progression of vein clearing to vein necrosis on GVCV-VRU1infected $V$. rupestris grapevine within 5 days. F, The second leaf from the shoot tip of GVCV-VRU2-infected vine showing vein clearing when photo was taken on 10 June 2015. G, The same leaf showing necrotic spots around terminal vein when photo was taken on 24 June 2015, indicating progression of vein clearing to vein necrosis on GVCV-VRU2-infected V. rupestris 'VRU1405' grapevine within 14 days. 
of GVCV genomes (Guo et al. 2014). Nucleotide identities of ORF II among GVCV isolates from commercial vineyards range from $83.5 \%$ between GVCV-CHA and GVCV-VRU1 to $99.2 \%$ between GVCV-VRU2 and GVCV-CMV2. Sequence analysis of ORF II demonstrated that GVCV-CMV2 and GVCV-VRU2 are closely related (Fig. 1), although they were isolated from two different grapevine species. On the other hand, GVCV-VRU1 and GVCVVRU2 are genetically diverse although they were found in the same $V$. rupestris species at close proximity of 100 yards apart in a native habitat. Similarly, GVCV-CMV2 and GVCV-CMV3 exist in the same grape cultivar Chardonel in the same commercial vineyard, but they only share $90.8 \%$ identity in ORF II. Locations of GVCV-VRU1/2 and GVCV-CMV2/3 are hundreds of miles apart. These results demonstrated that wild and cultivated grapevines are likely infected by multiple GVCV isolates that are neither limited to a region or specific to a variety. Presence of diverse GVCV isolates on same grape cultivars in the same vineyard and native habitats further suggest dynamic spread of evolving GVCV populations. It needs to be pointed out that genetic relationship analysis is based solely on the ORF II region, not the entire genome, for each sample, and thus only reveals a portion of genomic variation among the GVCV isolates.

GVCV-CHA is associated with vein clearing symptoms on young leaves that developed to mosaic symptom on mature leaves on Chardonel grapevines (Guo et al. 2014; Zhang et al. 2011). On the other hand, only mild vein clearing was observed on GVCVVRU1- or GVCV-VRU2-grafted Chardonel grapevines (Fig. 4). Mild symptoms appeared on GVCV-CHA-grafted $V$. rupestris grapevines (W. Qiu, unpublished data). In contrast, GVCV-VRU1 and GVCV-VRU2 are associated with vein clearing that progressed to vein necrosis along veins on mature leaves of $V$. rupestris grapevines (Figs. 2 and 3). Symptoms of GVCV-VRU1- and GVCV-VRU2infected $V$. rupestris differ in that yellow halos appeared around necrotic spots that are larger than those on GVCV-VRU1-infected mature leaves (Fig. 3E and G). Genomic and phenotypic differences between GVCV-CHA and the two isolates discovered in wild $V$. rupestris grapevine warrant a designation of them as novel GVCV isolates. Although the present and previous results support a close association between GVCV and the symptoms, it cannot be ruled out that other viruses may also be involved in symptom development. The causal relationship of GVCV to the vein clearing and necrosis symptom for completing the Koch's postulate will need to be confirmed by the infection of grapevine with an infectious GVCV construct.

Three phases likely occur before a new viral disease emerges: the pre-existing virus breaks the host species barrier and jumps from infected species to new hosts; the virus adapts to and changes genetically in the new host; and finally, the newly adapted virus spreads among new plant populations by transmission vectors (Elena et al. 2011, 2014; Jones 2009; Roossinck and García-Arenal 2015). This postulated scenario is supported by the results showing that genetically distinct wild strains of Pepino mosaic virus that were found in the populations of wild tomato species (Solanum spp.) in their native habitats of Peru are able to replicate efficiently in cultivated tomato crops (Moreno-Perez et al. 2014). Agroecological changes often trigger the emergence of new viruses and increase incidence of new viral diseases in crops (Fargette et al. 2006). The host species from which GVCV originated and spread to both wild and cultivated Vitis species are still not known. Genetically diverse GVCV isolates are now found in wild V. rupestris populations in their native habitats, suggesting that GVCV currently is endemic to the Midwestern states and indigenous in native Vitis populations. These isolates are closely associated with the vein clearing and necrosis symptoms on V. rupestris (Figs. 2 to 3) and with the mild vein clearing on the most susceptible cultivar 'Chardonel' (Fig. 4). These GVCV isolates in the reservoir populations of native wild grapevines form the foundation genetic pools for potential spillover among Vitis species. Moreover, perennial growth of Vitis species plants provides multiple exposures to transmission vectors over an extended period of time. Wild Vitis vines also readily proliferate by the rooting of stems to create multiple clones in native habitats. Grapevines of $V$. vinifera species from which the majority of cultivated grapevines are derived are not native to the Midwest region of the United States. Expansion of
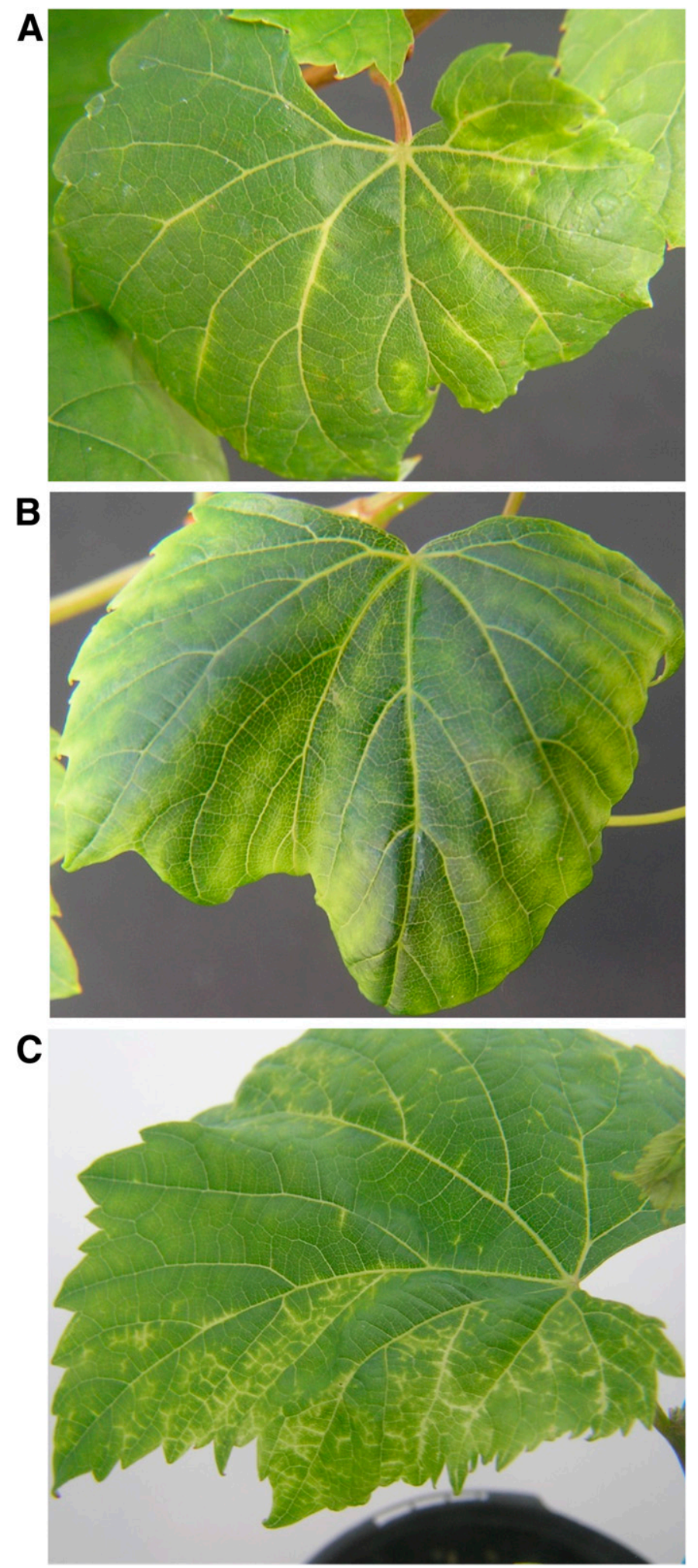

Fig. 4. Development of symptoms on the mature leaves of cultivar 'Chardonel' after it was grafted with Grapevine vein clearing virus (GVCV)-infected scion. A, GVCV-CHA-infected 'Chardonel' vine; B, GVCV-VRU1-infected 'Chardonel' vine; and C, GVCV-VRU2-infected 'Chardonel' vine. Symptoms were recorded 1 year after graft-transmission. 
commercial vineyards brings cultivated grapevines, such as $V$. vinifera-derived grape cultivars, in close proximity to wild Vitis populations in the Midwest. Therefore, the existence of a GVCV reservoir in native Vitis species and the potential for it to spill over into other wild Vitis species and cultivated grapes are concerns to the preservation of the declining wild Vitis populations and a challenge to the prevention of the increasing GVCV-associated disease in commercial vineyards.

\section{ACKNOWLEDGMENTS}

We thank P. Chang for the preliminary test of GVCV in Vitis samples. We thank J. Schoelz for critical reviewing of the manuscript. We also extend appreciation to S. Petersen, P. Mayer, and M. Odneal for correcting English for the manuscript. GenBank accession numbers are KJ725346 (GVCVVRU1) and KT907478 (GVCV-VRU2).

\section{LITERATURE CITED}

Bahder, B. W., Zalom, F. G., and Sudarshana, M. R. 2016. An evaluation of the flora adjacent to wine grape vineyards for the presence of alternative host plants of Grapevine red blotch-associated virus. Plant Dis. 100:1571-1574.

Borah, B. K., Sharma, S., Kant, R., Johnson, A. M., Saigopal, D. V., and Dasgupta, I. 2013. Bacilliform DNA-containing plant viruses in the tropics: Commonalities within a genetically diverse group. Mol. Plant Pathol. 14:759-771.

Di Gaspero, G., Copetti, D., Coleman, C., Castellarin, S., Eibach, R., Kozma, P., Lacombe, T., Gambetta, G., Zvyagin, A., Cindric, P., Kovacs, L., Morgante, M., and Testolin, R. 2012. Selective sweep at the Rpv3 locus during grapevine breeding for downy mildew resistance. Theor. Appl. Genet. 124:277-286.

Elena, S. F., Bedhomme, S., Carrasco, P., Cuevas, J., De La Iglesia, F., Lafforgue, G., Lalic, J., Prosper, Ã., Tromas, N., and Zwart, M. P. 2011. The evolutionary genetics of emerging plant RNA viruses. Mol. Plant-Microbe Interact. 24:287-293.

Elena, S. F., Fraile, A., and Garcia-Arenal, F. 2014. Evolution and emergence of plant viruses. Adv. Virus Res. 88:161-191.

Fargette, D., Konate, G., Fauquet, C., Muller, E., Peterschmitt, M., and Thresh, J. M. 2006. Molecular ecology and emergence of tropical plant viruses. Annu. Rev. Phytopathol. 44:235-260.

Geering, A., Mcmichael, L. A., Dietzgen, R. G., and Thomas, J. E. 2000. Genetic diversity among Banana streak virus isolates from Australia. Phytopathology 90:921-927.

Ghanem-Sabanadzovic, N. A., and Sabanadzovic, S. 2010. Two undescribed viral species isolated from native grapevines. (Abstr.). Phytopathology 100(suppl.):S2.

Guo, Q., Honesty, S., Xu, M. L., Zhang, Y., Schoelz, J. E., and Qiu, W. P. 2014. Genetic diversity, tissue and host specificity of Grapevine vein clearing virus. Phytopathology 104:539-547.

Hull, R., Geering, A., Harper, G., Lockhart, B. E., and Schoelz, J. E. 2005. Genus Badnavirus. Pages 392-396 in: Virus Taxonomy: 8th Report of the International Committee for Taxonomy of Viruses. C. M. Fauquet, M. A. Mayo, J. Maniloff, U. Desselberger, and L. A. Ball, eds. Elsevier Academic Press, San Diego.
Husmann, G. 1880. Pages 106-107 in: American Grape Growing and Wine Making. Orange Judd Company, New York.

Jacquot, E., Hagen, L. S., Jacquemond, M., and Yot, P. 1996. The open reading frame 2 product of Cacao swollen shoot badnavirus is a nucleic acidbinding protein. Virology 225:191-195.

Jones, R. C. 2009. Plant virus emergence and evolution: Origins, new encounter scenarios, factors driving emergence, effects of changing world conditions, and prospects for control. Virus Res. 141:113-130.

Klaassen, V. A., Sim, S. T., Dangl, G. S., Osman, F., Rwahnih, M. A., Rowhani, A., and Golino, D. A. 2011. Vitis californica and Vitis californica $\times$ Vitis vinifera hybrids are hosts for Grapevine leafroll-associated virus-2 and -3 and Grapevine virus A and B. Plant Dis. 95:657-665.

Martin, R. R., Polashock, J. J., and Tzanetakis, I. E. 2012. New and emerging viruses of blueberry and cranberry. Viruses 4:2831-2852.

Moreno-Perez, M. G., Pagan, I., Aragon-Caballero, L., Caceres, F., Fraile, A., and Garcia-Arenal, F. 2014. Ecological and genetic determinants of Pepino mosaic virus emergence. J. Virol. 88:3359-3368.

Pavek, D. S., Lamboy, W. R., and Garvey, E. J. 2003. Selecting in situ conservation sites for grape genetic resources in the USA. Genet. Resour. Crop Evol. 50:165-173.

Perry, K. L., Mclane, H., Hyder, M. Z., Dangl, G. S., Thompson, J. R., and Fuchs, M. F. 2016. Grapevine red blotch-associated virus is present in freeliving Vitis spp. proximal to cultivated grapevines. Phytopathology 106: 663-670.

Prendeville, H. R., Ye, X., Morris, T. J., and Pilson, D. 2012. Virus infection in wild plant populations are both frequent and often unapparent. Am. J. Bot. 99:1033-1042.

Qiu, W. P., Avery, J. D., and Lunden, S. 2007. Characterization of a severe virus-like disease in Chardonnay grapevines in Missouri. Published online. Plant Health Progress. doi:10.1094/PHP-2007-1119-01-BR

Roossinck, M. J. 2012. Plant virus metagenomics: Biodiversity and ecology. Annu. Rev. Genet. 46:359-369.

Roossinck, M. J., and García-Arenal, F. 2015. Ecosystem simplification, biodiversity loss and plant virus emergence. Curr. Opin. Virol. 10: 56-62.

Roossinck, M. J., Martin, D. P., and Roumagnac, P. 2015. Plant virus metagenomics: Advances in virus discovery. Phytopathology 105:716-727.

Roossinck, M. J., Saha, P., Wiley, G. B., Quan, J., White, J. D., Lai, H., Chavarría, F., Shen, G., and Roe, B. A. 2010. Ecogenomics: Using massively parallel pyrosequencing to understand virus ecology. Mol. Ecol. 19: 81-88.

Sandoval, C. R., Ramsdell, D. C., and Hancock, J. F. 1995. Infection of wild and cultivated Vaccinium spp. with blueberry leaf mottle nepovirus. Ann. Appl. Biol. 126:457-464.

Schoelz, J. E. 2008. Caulimoviruses: General features. Pages 457-464 in: Encyclopedia of Virology. Elsevier.

Xu, D., Mock, R., Kinard, G., and Li, R. 2011. Molecular analysis of the complete genomic sequences of four isolates of Gooseberry vein banding associated virus. Virus Genes 43:130-137.

Yasaka, R., Nguyen, H. D., Ho, S. Y. W., Duchene, S., Korkmaz, S., Katis, N., Takahashi, H., Gibbs, A. J., and Ohshima, K. 2014. The temporal evolution and global spread of Cauliflower mosaic virus, a plant pararetrovirus. PLoS One 9:e85641.

Zhang, Y., Singh, K., Kaur, R., and Qiu, W. 2011. Association of a novel DNA virus with the grapevine vein-clearing and vine decline syndrome. Phytopathology 101:1081-1090. 